\section{Vietnam Journal of Agricultural Sciences}

Received: June 11, 2020

\section{Correspondence to}

nguyenanhtru@vnua.edu.vn

\section{ORCID}

Nguyen Anh Tru

https://orcid.org/0000-0003-06151419

\title{
Development of High-tech Agriculture in the Context of Industrialization and Urbanization: The Case of Vietnam
}

\author{
Nguyen Anh Tru, Tran Huu Cuong \& Vu Ngoc Huyen
}

Faculty of Accounting and Business Management, Vietnam National University of Agriculture, Hanoi 131000, Vietnam

\begin{abstract}
The aim of this article is to assess the importance and development of high-tech agriculture in Vietnam under the context of industrialization and urbanization. Due to pressure from international economic integration and climate change in recent years, high-tech agriculture seems to be an affordable direction for Vietnam to renovate the agricultural sector. Although high-tech agriculture has existed in different locals and sub-sectors of agriculture such as crop, livestock, and aquaculture, and Vietnam has obtained initial achievements in adopting high-tech agriculture, this country has to face a number of challenges related to land, credit, information technology, and human resources in the process of developing hightech agriculture. Lastly, policies are recommended to facilitate the development of high-tech agriculture in Vietnam.
\end{abstract}

\section{Keywords}

High-tech agriculture, industrialization, urbanization, Vietnam

\section{Introduction}

By 2050, the world must produce 70 percent more food, using less energy, fertilizer, and pesticides while lowering levels of greenhouse gases (GHGs) and coping with climate change. To deal with these issues, agriculture 4.0 has been created with the central roles of science and technology. This means the future of agriculture will use sophisticated technologies such as robots, temperature and moisture sensors, aerial imaging, and global positioning system (GPS) technology, which will support businesses to operate more profitably, efficiently, safely, and environmentally friendly. With agriculture 4.0, farmers can use the minimum quantities of water, fertilizers, and pesticides across entire fields (Clercq et al., 2018).

Many countries all over the world have encouraged the application of modern technology in agriculture, especially the technologies of the $4^{\text {th }}$ Industrial Revolution. In developed countries, "precision agriculture" or "smart farming" are common concepts 
before the occurrence of "Agriculture 4.0". In the U.S., the first official definition of "precision agriculture" (PA) was proposed by the U.S. House of Representatives in 1997, which identified PA as an integration of information and production-based farming system that is designed to increase long-term, site-specific, and whole-farm production efficiency, productivity, and profitability as well as minimizing any unintended effects on wildlife and the environment (Gebbers \& Adamchuk, 2010). In the European Union (EU), about $70-80$ percent of new farm equipment traded in the market has some content of PA (EU, 2014). Between 2018 and 2020, the EU committed to spending around 100 million EUR to facilitate the application of digital technology in agriculture. The main purpose of this budget is to train farmers to use new technology, develop data analysis tools, invest in digital infrastructure, establish an innovation ecosystem, and construct digital and data platforms for agriculture. In Asia, the Republic of Korea began implementing the strategy "Agriculture's smartization" in 2013 to expand the adoption of the Information and Communication Technologies (ICT) and the model of smart farming across the country. In Taiwan, the "Productivity 4.0 Initiative" for the period 2016-2024 was approved in 2015, in which one important component is the “Agricultural Productivity 4.0" program. This program includes two main orientations, namely smart production and digital services. In Thailand, "Agriculture 4.0" has been defined as one of three pillars of the "Thailand 4.0" initiative (PRD, 2017).

The export turnover of agro-products of Vietnam is still very low because most of the agricultural commodities of this country have been produced by backward production technologies, exporting in raw forms or, in other words, just supplying raw materials for foreign companies to further process them into higher value items. Thus, technology innovation in agricultural development in combination with high-tech applications in agriculture is the right direction for Vietnam to increase the productivity, quality, and value of agricultural products (Le Tat Khuong \& Tran Anh Tuan, 2014).
Vietnam lags behind regional peers such as Thailand and China in agricultural land, labor, and water productivity, and these have led to a decline of the total factor of productivity in recent years. In the domestic market, concerns about food safety are growing. Further, Vietnamese agriculture is facing domestic competition from cities, industries, and services for laborers, land, and water. As a result, overuse of inputs (fertilizer, pesticides, etc.) and natural resources, which impact both the environment and farmer profitability, are increasing. Some environmental problems negatively affect both productivity and the international position of Vietnam's commodities (World Bank, 2016).

Although Vietnam has gained some achievements on developing high-tech agriculture in recent years, the adoption of hightech agriculture still presents limitations such as low labor productivity, low efficiency, and low income for farmers, and high-tech agriculture has only been applied in some big businesses (Nguyen Xuan Cuong, 2019).

In Vietnam, the agriculture sector employs the most natural and human resources of the country. The development of high-tech agriculture enhances not only economic efficiency, but also helps achieve sustainable environmental development. Therefore, the development of high-tech agriculture has been defined as a feasible alternative for countries that depend on the agricultural economy like Vietnam (Nguyen Thi Ngoc Anh, 2020). Due to agricultural development, the ecological environment in Vietnam is degraded and worsening the livelihoods of humans. Further, the processes of globalization, urbanization, and industrialization of the economy facilitates agricultural production, but they may also lead to unsustainable development (Nguyen Thanh Tuan \& Nguyen Duc Hoang Tho, 2020). High-tech agriculture has been identified as an alternative to boost production efficiency, achieve sustainable development, and minimize unintended impacts on the environment in Vietnam, especially in the expansion of industrialization and urbanization. This article aims to assess the importance and development of high-tech agriculture in Vietnam under the 
context of industrialization and urbanization. More importantly, policies are recommended to facilitate the growth of high-tech agriculture in this country.

The remainder of the paper is organized as follows. The second section analyzes the definitions, characteristics, and roles of high-tech agriculture. The third section presents the research methodologies. The fourth section highlights an overview of high-tech agriculture in countries around the world and lessons for Vietnam. The fifth section analyzes the effects of industrialization and urbanization on high-tech agriculture in Vietnam. In the sixth section, we discuss high-tech agriculture in Vietnam. Lastly, conclusions and policy implications are summarized in the seventh section.

\section{Definitions, Characteristics, and Roles of High-tech Agriculture}

\section{Definitions}

In Western countries, high-tech agriculture is defined as advanced agriculture by employing modern technology, biotechnology, environment, and ecology in order to develop agriculture in a safe and sustainable orientation such as green agriculture, organic agriculture, and ecological agriculture. The main purpose of high-tech agriculture is to produce and supply enough agricultural products to the society in addition to protecting the natural environment (Duong Anh Dao, 2012).

According to Chinese scientists, high-tech agriculture is the adoption of new technologies such as biotechnology, information technology, cosmos technology, and automatization, etc. in agricultural production.

In India, since 1999, the term "high-tech agriculture" has been understood as all modern technologies, which depend less on the environment, that are applied in agriculture in order to enhance productivity and improve the quality of agricultural products (Duong Anh Dao, 2012).

In Vietnam, high-tech agriculture is identified as modern farming methods that reduce the costs of inputs and increase the value of agricultural products in addition to making them safe and environmental-friendly (Duong Anh Dao, 2012; Luu Tien Dung \& Nguyen Thi Kim Hiep, 2017).

\section{Characteristics}

First, the objects of high-tech agriculture are crops and animals. However, unlike traditional agriculture, high-tech agriculture creates new varieties that are of a high quality and have shorter life cycles. Second, soil may be substituted by another landscape due to reductions of cultivated land areas in the world. Third, hightech agriculture is integrated with advanced technologies. Fourth, massive quantities of agricultural products are produced by adopting high-tech agriculture. Last, the production process of high-tech agriculture is a perfect round, running from research to production and consumption (Duong Anh Dao, 2012).

\section{Roles}

First, high-tech agriculture produces and supplies food to humans to ensure the development of socio-economics and provides raw materials to processing industries. Second, high-tech agriculture assists in attracting resources from both domestic and foreign individuals and organizations in order to develop the agriculture sector. Third, high-tech agriculture is in charge of boosting yields and improving the quality as well as reducing production costs of agricultural products. Fourth, high-tech agriculture assists in improving the abilities of laborers and adjusting the labor structure. Fifth, high-tech agriculture encourages people to maximize land use and increases the significance of land. Finally, high-tech agriculture facilitates the industrialization and modernization of the country (Duong Anh Dao, 2012).

\section{Research Methodology}

\section{Data collection}

Secondary data for this research was gathered from various sources, including reports and studies released by the General Statistics Office of Vietnam, the Food and Agriculture Organization of the United Nations (FAO), and the World Bank. 


\section{Methods of analyses}

Descriptive statistics were employed to analyze the effects of industrialization and urbanization on high-tech agriculture and describe the importance and development of high-tech agriculture in Vietnam. For instance, the trend of contribution of sectors, namely agriculture, forestry, and fishery (AFF), and industry and construction, and services to GDP for five years (2012-2016) has been discussed to address that contribution of AFF to the Vietnamese economy tends to decrease, while contribution of services to the economy increases. Further, index of industrial production of Vietnam tended to increase between 2012 and 2016 and this implies a rise of industrialization process in the country. Lastly, the urban population rate of Vietnam increased by 6.1 percent from 29.1 percent in 2008 to 35.2 percent in 2017 and this reflects the development of urbanization in this country.

\section{An Overview of High-tech Agriculture in the World and Lessons for Vietnam}

\section{High-tech agriculture in the U.S.}

In the U.S., the government has adopted technological advances on agriculture in order to enhance productivity since the early $20^{\text {th }}$ century. Since the early 1980 s, there have been more than 100 scientific and technological zones for agriculture.

Agriculture practices that have been applied in this country include high-tech irrigation systems, new variety development, biotechnological advances in planting, and genetically modified organisms (GMOs). Agricultural production in traditional farms in the U.S. has been transformed into modern production based on science, research, and development such as high-yielding GMO potatoes and slim-trunk banana varieties (Nguyen Thu Phuong, 2018).

\section{High-tech agriculture in the Netherlands}

With a strategy of "high investment massive production", agricultural infrastructures of the Netherlands have been known as the most modern in the world, including irrigation systems and greenhouses (over 11,000 hectares, accounting for 25 percent of total area of the world's greenhouses) along with modern and automatic facilities and equipment. Consequently, production performance is 5-6 times higher than that of outdoor production (Duong Anh Dao, 2012).

Every year, this country sells to the market about 5.5 thousand types of cut flowers, 2 thousand varieties of plants, 2.2 thousand types of horticulture plants, and 7 billion root flowers, on average. There are about 200 varieties of tulip grown in the Netherlands on 8.5 thousand hectares. Several high-yielding fruits and vegetables are produced in this country such as tomatoes (600-700 tons/hectare/year), sweet chilies (300 tons/hectare/year), apples, and peas (20 tonnes/hectare/year). The market share of potatoes exported from the Netherlands accounts for 60-70 percent of the global market. The Dutch husbandry sector is extremely developed with 20 million dairy-cows, 20 million meatcows, 13.5 million pigs, and nearly 100 million chickens. Further, the aquaculture sector also presents high efficiency (Duong Anh Dao, 2012).

The success of Dutch agriculture is a result of the following reasons: (1) construction and adjustment of production structures to foster the competitive ability of agricultural production in the world market; (2) innovation of production practices by increasing production scales and investments, and adopting technological advances in production; (3) development of farm and agricultural cooperative models toward specialization; and (4) establishment of important roles for the State in policy involvement, market, and infrastructure development, and environment protection (Duong Anh Dao, 2012).

\section{High-tech agriculture in Israel}

Since the early 1980s, ten high-tech agricultural zones have been constructed in Israel that created a total revenue of 200,000 USD per hectare. With greenhouse technology, tomato yields reached 300 tonnes/hectare, which is four times higher than that of outdoor production. Israel only has 360,000 hectares of arid soil for agriculture and a shortage of water, but it 
produces and supplies enough food for domestic demands and exports. Within the past 5 years, the value of agricultural production of this country exceeded 3.5 billion USD, in which exports now account for more than 20 percent. Currently, an Israeli farmer can produce enough to feed 100 people (Nguyen Thu Phuong, 2018).

The above achievements are the result of efforts of the Israeli government in constructing a national plan for high-tech agriculture development with the stages of planning, constructing projects, and managing projects. Israel has been known as a leading country in terms of distributing national budgets to research and implementing high-tech agriculture. Recently, this country has been able to control the volume and quality of agricultural products such as fruits and vegetables, milk, eggs, potatoes, and chickens (Nguyen Thu Phuong, 2018).

\section{High-tech agriculture in India}

Starting in the early $21^{\text {st }}$ century, the Indian government began to implement the second renovation in agriculture which has three major themes as follows: (1) enforcement of investments in agriculture; (2) priority of electrification in rural areas and irrigation; and (3) eradication of subsidy mechanisms in agriculture and enhancement of international cooperation in agriculture $(\mathrm{Vu}$ Thi Thuy Hang, 2019).

This country enacted many policies related to high-tech agriculture. First, the expansion of accessing advanced technologies. The main objective of this policy is to foster productivity, reduce production costs, and improve the quality of agricultural products. Second, enhancement of adopting information technology on agriculture in order to promote information support services to farmers. By April 2016, this country released the electronic National Agriculture Market (eNAM) which covers 585 wholesale markets across the country. In addition, the electronic farm (e-Farm) program has been developed to assist consumers in terms of decreasing concerns about food reservation. Third, concentration on training high-quality human resources to satisfy the requirements of modern agriculture. Fourth, investment in market research and infrastructures. Fifth, the State assists farmers in establishing and looking for markets for their products (Vu Thi Thuy Hang, 2019).

\section{Lessons for Vietnam}

Some lessons have been identified and can be applied to the development of high-tech agriculture in Vietnam. First, construction on high-tech agriculture zones expresses the interests of the State in agriculture, farmers, and rural communities. Second, biotechnology is defined as an essential assignment. Third, support policies from the government for developing high-tech agriculture zones is necessary. Fourth, the success of high-tech agriculture needs to be supported by various factors such as infrastructure, land, capital, typology, and climate. Finally, it is necessary for Vietnam to develop human resources for hightech agriculture.

\section{Effects of Industrialization and Urbanization on High-tech Agriculture in Vietnam}

In the eleven years following reunification, the unified country followed the socialist development model placing greater emphasis on rural areas and on building a 'planned economy' that entailed the distribution and concentration of industries in select centers. Since the implementation of "Doi Moi" policies in 1986, the Vietnamese government began to introduce liberal market mechanisms, which encourage private-sector initiatives, while retaining its role as the nation's strategic planner and enforcer. Although Vietnam has embarked on a trajectory of rapid economic liberalization with the inception of Doi Moi, its government has also implemented a variety of policies to facilitate a more even distribution of economic growth and urban development. For instance, Government Decision No. 10 in 1998 on the Urban System and Development Strategy to 2020 called for the development of medium and small sized cities while containing the growth of the largest cities. Subsequently, the Government accepted the possibility of the rise of mega-cities with populations over 10 million (Government 
Decision No. 445 in 2009). The 2011-2020 Socio-Economic Development Strategy accepts that urbanization will be necessary to promote the country's goals of industrialization and modernization (World Bank, 2011).

Over a five-year period, the share of agriculture, forestry, and fisheries (AFF) contributing to the gross domestic product (GDP) of Vietnam decreased by about 3 percent from more than 19 percent in 2012 to more than 16 percent in 2016. By contrast, the contribution of services to the GDP increased by about 3 percent in the same period, while industry and construction (IC) contributed about 33 percent to the GDP. These imply that the economic structure of Vietnam has been transformed through reducing the contribution of AFF, while increasing contributions of services and IC to the economy (Table 1).

As seen in Table 2, the index of industrial production of Vietnam presents a moderate growth for the half decade from 2012 to 2016, especially in the sub-sectors of electricity, gas, steam, and air conditioning supply and manufacturing (Table 2).

The proportion of the Vietnamese urban population increased by about 6 percent from about 29 percent in 2008 to more than 35 percent in 2017. This reflects the trend of urbanization in this country (Figure 1).

During the decade from 2007 to 2016, the percentage of the Vietnamese urban population having access to electricity reached 100 percent, and this implies that all households in urban areas can use electricity for their living needs (Figure 2).

As seen in Table 3, the area of new housing construction in Vietnam increased by about 12 million square meters from more than 81 million square meters in 2012 to more than 93 million square meters in 2015. In terms of housing type, most construction areas were private houses. In the whole country, regions with large areas of housing construction included the Red River Delta, Mekong River Delta, and North Central and Central coastal areas (Table 3).

\section{High-tech Agriculture in Vietnam}

\section{The importance of high-tech agriculture to Vietnam}

Due to the adverse effects of climate change, the agriculture sector in Vietnam will face major changes by the end of the century. For example, the salinization of the Mekong Delta and the decrease in agricultural land highlight the issues

Table 1. Contributions of economic sectors to the gross domestic product of Vietnam (\%)

\begin{tabular}{lccccc}
\multicolumn{1}{c}{ Items } & $\mathbf{2 0 1 2}$ & $\mathbf{2 0 1 3}$ & $\mathbf{2 0 1 4}$ & $\mathbf{2 0 1 5}$ & $\mathbf{2 0 1 6}$ \\
\hline Agriculture, forestry, and fisheries (AFF) & 19.22 & 17.96 & 17.70 & 17.00 & 33.25 \\
Industry and construction (IC) & 33.56 & 33.19 & 33.21 & 32.72 \\
Services & 37.27 & 38.74 & 39.04 & 39.73 \\
Products taxes less subsidies on production & 9.95 & 10.11 & 10.05 & 10.02 \\
Total & 100.00 & 100.00 & 100.00 & 100.00 \\
\hline
\end{tabular}

Source: General Statistics Office of Vietnam (2017)

Table 2. Index of industrial production of Vietnam (\%)

\begin{tabular}{|c|c|c|c|c|c|}
\hline Items & 2012 & 2013 & 2014 & 2015 & 2016 \\
\hline Mining and quarrying & 105.0 & 99.4 & 102.4 & 107.1 & 93.2 \\
\hline Manufacturing & 105.5 & 107.6 & 108.7 & 110.5 & 111.3 \\
\hline Electricity, gas, steam, and air conditioning supply & 111.5 & 108.4 & 112.5 & 111.4 & 111.5 \\
\hline Water supply, sewage, waste management, and remediation activities & 108.2 & 109.5 & 106.3 & 106.9 & 108.0 \\
\hline Total & 105.8 & 105.9 & 107.6 & 109.8 & 107.4 \\
\hline
\end{tabular}

Source: General Statistics Office of Vietnam (2017) 


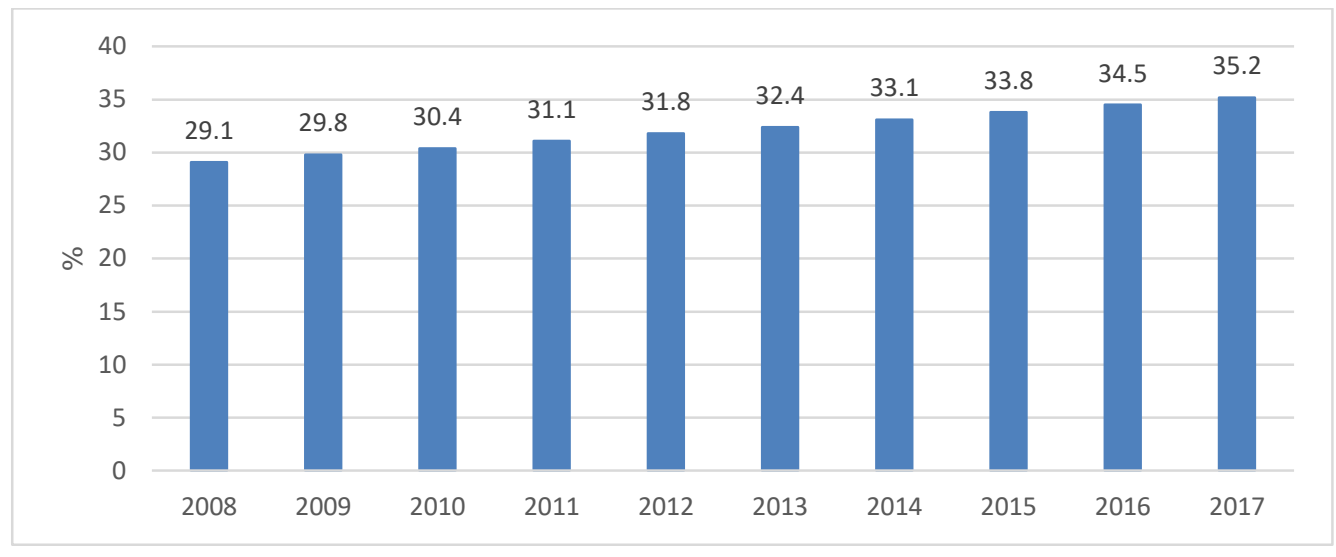

Figure 1. Urban population changes in Vietnam over a ten year period Source: World Bank (2020d)

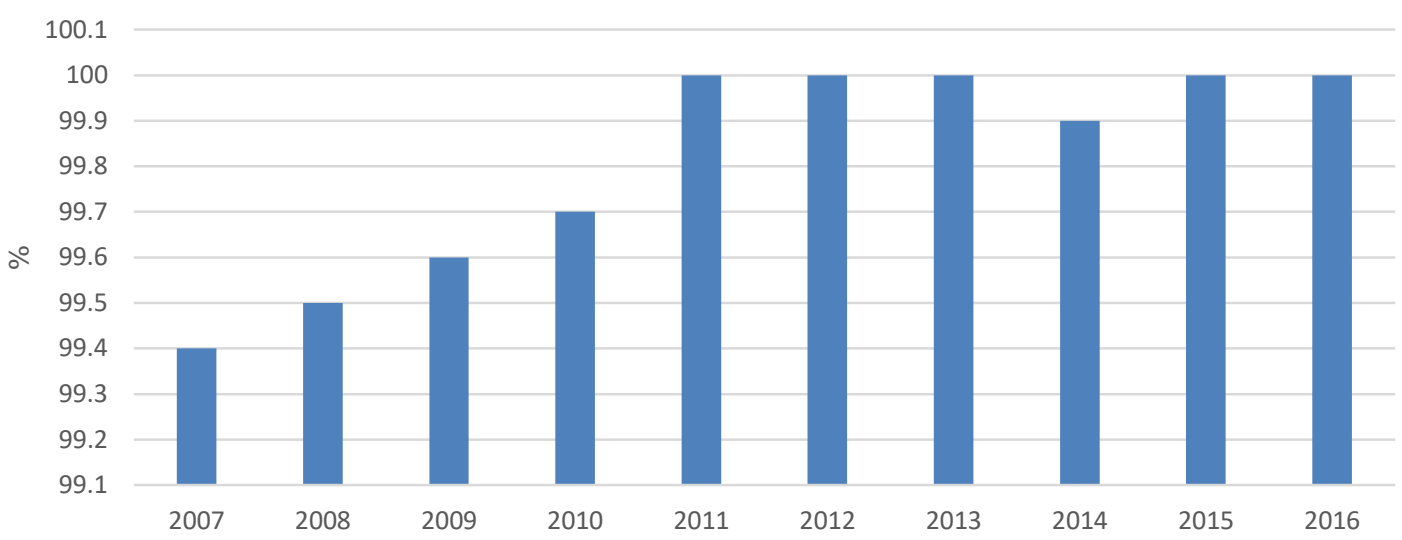

Figure 2. Urban population access to electricity in Vietnam over a ten year period Source: World Bank (2020e)

Table 3. Area of new housing construction by type of house and by region in Vietnam (thousand $\mathrm{m}^{2}$ )

\begin{tabular}{cccc}
\hline Items & $\mathbf{2 0 1 2}$ & $\mathbf{2 0 1 3}$ & $\mathbf{2 0 1 4}$ \\
Type of house & & & \\
Apartment & 1,844 & 3,361 & 2,326 \\
Private house & 79,469 & 83,260 & 97,517 \\
Region & & 2,324 & 21,618 \\
Red River Delta & 18,841 & 22,345 & 12,662 \\
Northern midlands and mountainous areas & 10,829 & 12,329 & 19,023 \\
North Central and Central coastal areas & 17,382 & 17,717 & 14,327 \\
Central Highlands & 5,321 & 5,640 & 19,237 \\
South East & 10,338 & 10,875 & 1,271 \\
Mekong River Delta & 18,602 & 17,715 & 19,303 \\
Total & 81,313 & 86,621 & 89,843 \\
\hline
\end{tabular}

Source: General Statistics Office of Vietnam (2017) 
the nation will face. High-tech and climate-smart agriculture, which incorporate sustainability, economic growth, and environmental pressures, can formulate new farming methods and products to mitigate this trend. The government has already taken steps in promoting high-tech agriculture with its 4.4 billion USD credit line for high-tech agriculture projects. To maintain growth and commitment to high-tech and climate-smart agriculture from farmers in the region, introducing a pilot program or proof of concept to stakeholders will build trust and buyin that will ultimately lead to implementation (Ong, 2017).

As seen in Figure 3, the proportion of agricultural land of Vietnam increased by nearly 7 percent from more than 32 percent in 2007 to more than 39 percent in 2016 due to the exploitation of non-use land areas. However, in the last three years of the period (2014-2016), the rate of agricultural land remained nearly stable at about 39 percent (Figure 3).

In Vietnam, the GDP growth rate was higher than the AFF growth rate between 2007 and 2016. The AFF growth rate dropped by nearly three times from 4 percent in 2007 to 1.4 percent in 2016, while the GDP growth rate decreased by nearly one percent in the same period. During the period of 2014-2016, the AFF growth rate sharply declined, while the GDP growth rate remained stable at more than 6 percent. This suggests that the economic growth of Vietnam tends to depend on other sectors such as industry and services rather than AFF (Figure 4).

The crop, livestock, and food production indices of Vietnam significantly increased for a decade (2007-2016), especially in the livestock production index. This implies remarkable achievements of this country in the programs concerning food security for this decade and the transformation in the structure of the agricultural sector by increasing the share of the livestock sub-sector and reducing the contribution of the crop sub-sector (Figure 5).

In Vietnam, there are a number of sources leading to carbon dioxide $\left(\mathrm{CO}_{2}\right)$ emissions in agriculture. The majority of $\mathrm{CO}_{2}$ emissions in agriculture are caused by rice cultivation, followed by synthetic fertilizers. Thus, it is necessary to foster high-tech agriculture in order to build up advanced cultivation practices and fertilizer applications to reduce $\mathrm{CO}_{2}$ emissions in agriculture (Figure 6).

The gross output of products from cultivated land increased by about 12 million VND (516 USD) from more than 72 million VND in 2012 to more than 84 million VND in 2016, while the gross output of products from aquaculture increased by about 42 million VND (1,806 USD) in the same period. These results imply the importance of the adoption of science and technology in agriculture in terms of enhancing the gross value of products per hectare (Table 4).

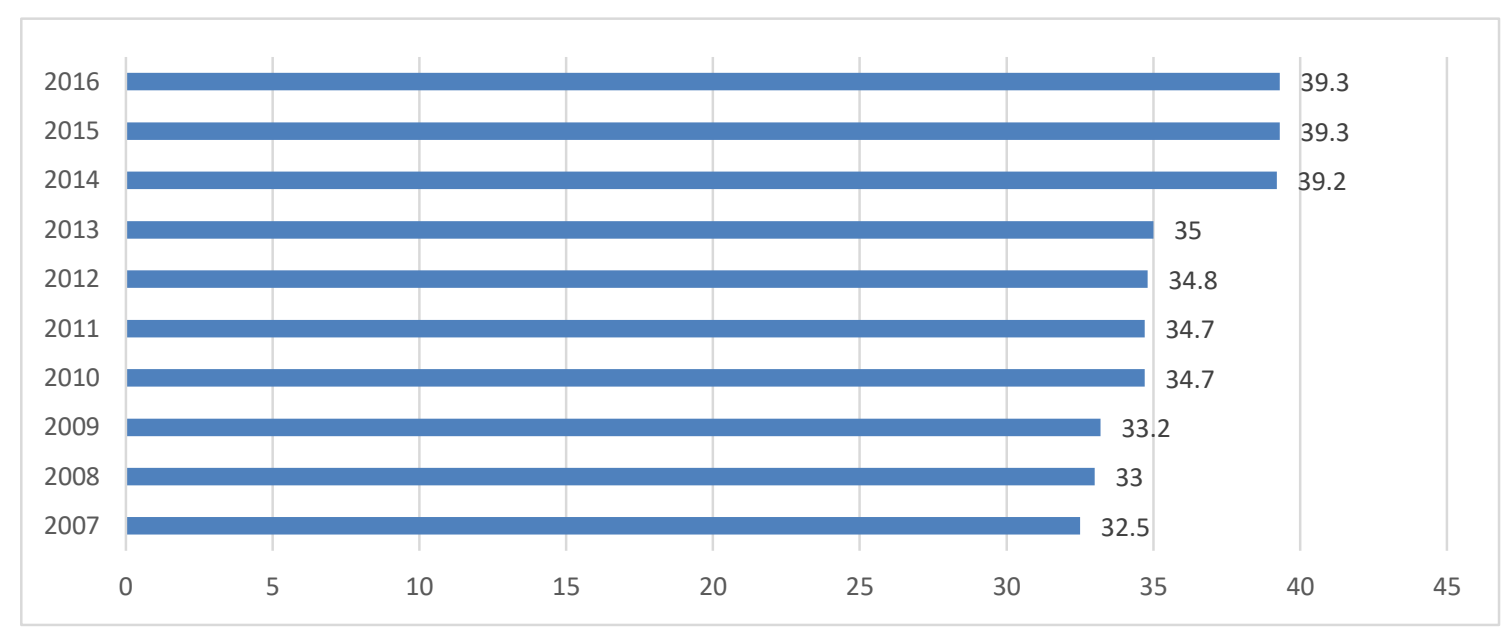

Figure 3. Percentages of agricultural land out of the total land area of Vietnam Source: World Bank (2020c) 


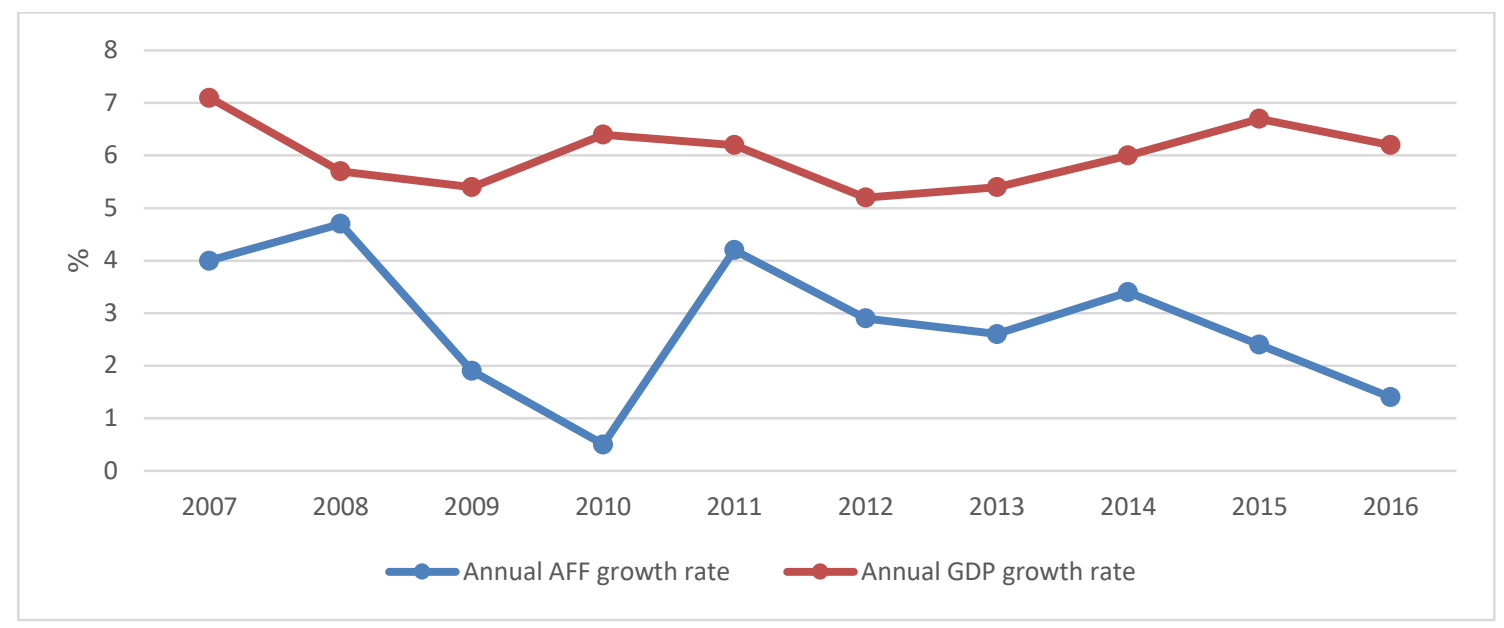

Note: AFF denotes agriculture, forestry, and fisheries. GDP means gross domestic product.

Figure 4. Annual growth rate of AFF and GDP of Vietnam

Source: World Bank (2020a)

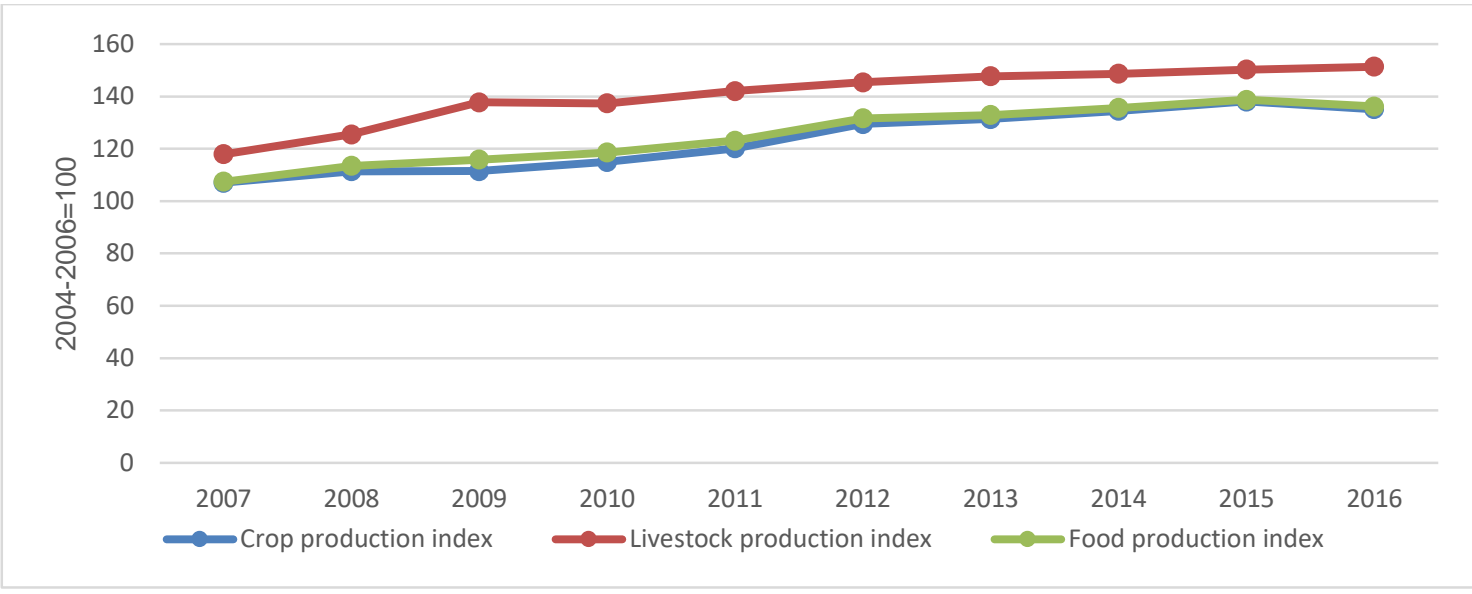

Figure 5. Crop, livestock, and food production indices of Vietnam

Source: World Bank (2020b)

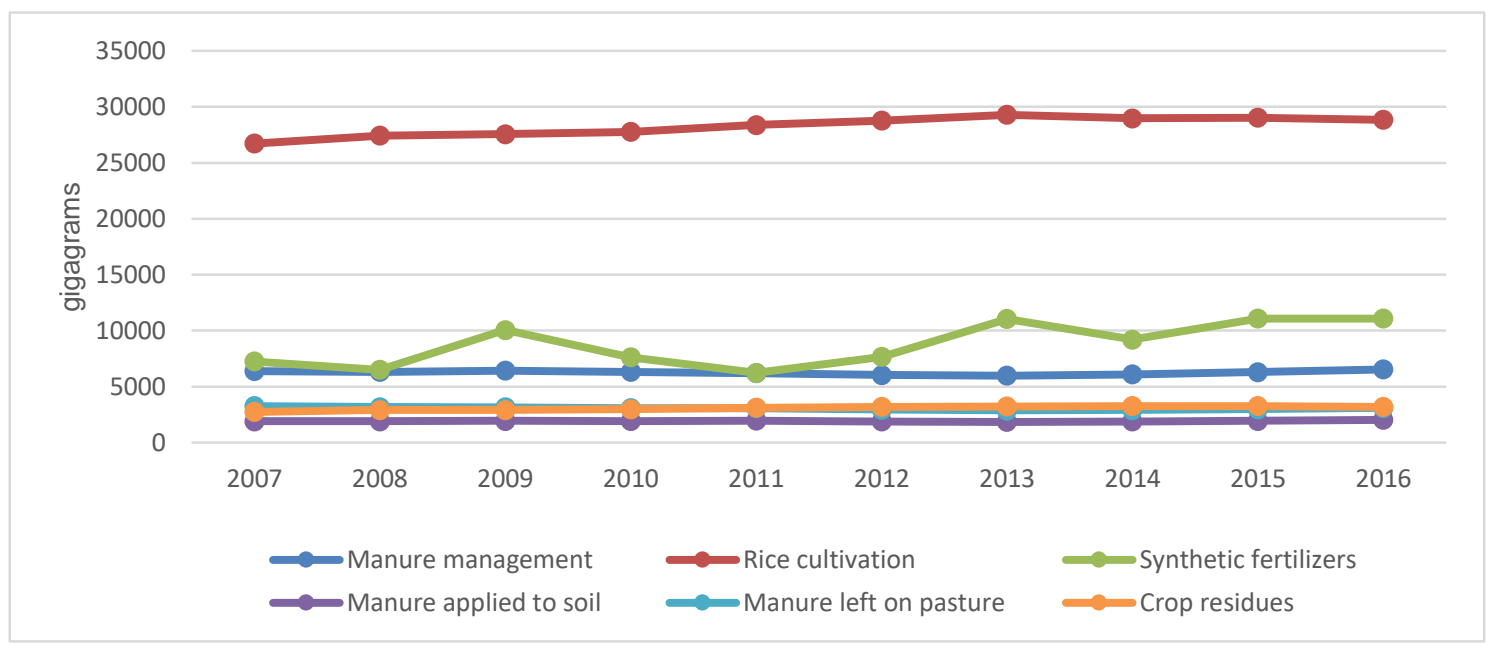

Figure 6. Carbon dioxide emissions in agriculture of Vietnam

Source: FAO (2020) 
Table 4. Gross output of products per hectare of cultivated land and aquaculture water surfaces in Vietnam (million VND)

\begin{tabular}{cccccc}
\hline Items & 2012 & 2013 & 2014 & 2015 & 2016 \\
\hline Cultivated land & 72.8 & 75.7 & 79.3 & 82.6 & 84.5 \\
Aquaculture water surfaces & 145.3 & 157.6 & 177.4 & 178.1 & 187.1 \\
\hline
\end{tabular}

Source: General Statistics Office of Vietnam (2017)

Note: VND means Vietnam Dong (Vietnamese currency unit)

There are numerous reasons that have been identified to develop high-tech agriculture in Vietnam. First, there are drawbacks to the development of agriculture in Vietnam in recent years. According to the estimation of the General Statistics Office of Vietnam, by January 2019, there were nearly 5.7 thousand households in poverty (equivalent to 19.6 thousand poverty inhabitants). Although agriculture contributes only 20 percent of the GDP, the number of agricultural laborers decreased by about 1.6 million from 20.8 million in the first quarter of 2018 to 19.2 million in the same period of 2019. Technological progress in agriculture is evaluated to lie between Agriculture 1.0 and Agriculture 2.0. Natural disasters such as typhoons, floods, and drought, and risks related to deforestation, soil erosion, and environmental pollution negatively affect agricultural production and exportation.

Second, the development of high-tech agriculture is a crucial trend in recent times, especially in developing countries like Vietnam. For instance, Vietnam is concentrating on developing the economy, but sometimes social and environmental issues have been neglected. Thus, sustainable agricultural development models should be encouraged since these are suitable for the development of Vietnamese agriculture.

Third, Vietnam has huge potentials for developing high-tech agriculture. By 2018, 22 high-tech agricultural zones were planned based on the decision of the Prime Minister; 35 hightech agricultural enterprises were approved by the Ministry of Agriculture and Rural Development; and 3 high-tech agricultural areas have been approved by provinces and cities in the whole country. Support policies on science and technology are essential motivators to foster agricultural growth, and technological advances contribute about $30-40$ percent to agricultural growth. The number of firms operating in the agriculture, forestry, and fishery industry increased from 3,517 enterprises in 2012 to 4,500 enterprises in 2016 and 5,661 in 2017. In addition, the expansion of start-up enterprises in agriculture is attractive to young laborers and corporations in recent years. For example, some corporations are investing in high-tech agriculture such as VinEco Agricultural Investment, Development and Productions, LLC. (a member of Vingroup), TH Group, and Viet UC Seafood Corporation, etc. This is an important element to establish high-tech agricultural corporations in Vietnam.

Fourth, policies on the development of socio-economics of Vietnam support developing high-tech agriculture. The development of hightech agriculture is one of the prioritized directions that was presented in policies issued by the Vietnam Communist Party and the Government of Vietnam, including the High-tech Law in 2009, Decision No. 176/QD-TTg issued by the Prime Minister on 29 January 2010 on the Approval for a Plan of Application of High-Tech Agriculture toward 2020, Decree No. 55/ND-CP of the Government on Preferential Loans for Agriculture and Rural Development, the Plan for Development of High-Tech Agriculture issued of the Ministry of Agriculture and Rural Development, and a credit package of 100,000 billion VND provided to high-tech agricultural enterprises (Nguyen Thi Ngoc Anh, 2020).

\section{Policies on High-tech Agriculture of Vietnam}

\section{The high-tech law}

This law was issued by the National Assembly of Vietnam on July 1, 2009. The main scope of this law is to regulate high-technology policies and solutions in order to encourage and foster high-tech activities. 


\section{Decision 2457/QD-TTg of the Prime Minister}

This decision was issued by the Prime Minister on December 31, 2010, and regulates the approval of the national program on development of high-tech until 2020. The overall aim of this decision is the promotion, ownership, and creativity of high-tech; efficient application of high-tech to socio-economic sectors; product manufacturing and establishment of high-tech industries; and construction of infrastructure and human resources for high-tech.

\section{Decision 1895/QD-TTg of the Prime Minister}

This decision was issued by the Prime Minister on December 17, 2012, and refers to the approval of the program in development of hightech agriculture within the National Program on Development of High-Tech toward 2020. The decision demonstrates three major objectives in the period 2016-2020. First, enforcement of developing high-tech in agriculture in order to create from two to three new varieties for crops, cattle, and aquaculture, which have high yield, premium quality, and adequate disease resistance. Second, enforcement of the adoption of high-tech agriculture on the production of agri-products that have high yield, premium quality, competitive capacity, and are safe to enhance the share of high-tech agricultural products which currently accounts for about 35 percent of the total value of agricultural production in whole country. Third, establishment of 200 agricultural enterprises that can adopt high-tech in provinces and cities located in pilot economic zones; and the construction of one or two high-tech agricultural zones in each agricultural-ecology zone.

\section{Decision 575/QD-TTg of the Prime Minister}

This decision was issued by the Prime Minister on May 4, 2015, and regulates the overall plan on high-tech agricultural zones until 2020 and the direction toward 2030. The decision addresses specific goals until 2020 and toward 2030.

Until 2020:

(1) Construct ten high-tech agricultural zones; (2) concentrate on key agri-products in the high-tech agricultural zones, including vegetables, fruit, coffee, tea, dragon fruit, cows, poultry, and shrimp; (3) develop legislation, organization, and human resources for the hightech agricultural zones; and (4) construct mechanisms and policies for the high-tech agricultural zones.

Toward 2030:

(1) Complete the build-up of infrastructure for the high-tech agricultural zones; and (2) expand the scope and objectives for the high-tech agricultural zones.

\section{Decision 19/QD-TTg of the Prime Minister}

This decision was issued by the Prime Minister on April 19, 2018, and regulates the criteria, rights, procedures, and formalities for high-tech agricultural enterprises.

\section{Aspects of High-tech Agriculture in Vietnam}

In Vietnam, science and technology applications in agricultural production are engaged by various stakeholders such as the State, scientists, businesses, and farmers. A credit package of 4.4 million USD with interest rates $0.5-1.5$ percent lower than the average interest rate for high-tech and clean agriculture, has been provided to agricultural enterprises to expand their production. Commercial banks in Vietnam, namely Agribank, Vietcombank, and the Bank for Investment and Development of Vietnam (BIDV) are in charge of offering credit packages for these high-tech agriculture project loans disbursed for agriculture equipment, technology, production, fertilizer, and pesticides. A recent issue of enterprises is that their property and assets are not acceptable collateral for bank loans. Other incentives are also available for investments to manufacture agricultural equipment or production of biological products. If an enterprise builds a plant to process agro-forestry-aqua products, the government will support up to 60 percent of the total investment which is equivalent to 7 billion VND (318,000 USD).

Apart from national incentives, many cities and provinces have established specific 
mechanisms to assist businesses and attract more investors. Some locations have become desirable destinations for high-tech agricultural businesses, such as Ho Chi Minh City, Lam Dong, Vinh Phuc, and Quang Ninh provinces. Currently, Vietnam has three high-tech agricultural zones in Hau Giang, Phu Yen, and Bac Lieu provinces. In addition, 28 agricultural businesses applying high technologies are certified by the government. Nine firms specialize in growing vegetables and flowers, eight others breed animals, and eleven operate in aquaculture. Three other provinces have plans to construct high-tech agricultural zones, namely Thai Nguyen, Thanh Hoa, and Lam Dong provinces. By the end of 2017, there were 15 high-tech agricultural projects supported by the government. Investments of the State range from 156.3 billion VND to 284.5 billion VND. Most projects have small and medium scales and consequently, these have negligible impacts on society and industry. Some high-tech projects applied in agricultural zones are inconsistent because of capital shortages and unfavorable locations.

In the domestic market, many corporations, companies, and large enterprises invest more in high-tech agriculture such as Hoang Anh Gia Lai Group, Hoa Phat Group, and Vingroup. For example, Loc Troi Group, through its Centre for Research and Production of Biological Products, has produced advanced and high-quality bioorganic crop protection products. TH True Milk uses world-class technologies for its water purification, cattle breeding, management software system for monitoring animal health, comfort, and milk production, and dairy processing plant. Vingroup is implementing the first phase of a 650 billion VND (29.8 million USD) high-tech agricultural center project on 43 out of 200 hectares, producing about 20 types of vegetables and fruits based on VietGap standards. Cutting-edge technologies from Japan, Israel, and the Republic of Korea are employed to ensure products meet VietGap, GlobalGap, and organic food standards. They are striving to shape a high-tech agricultural production zone with a center for procuring, processing, and preserving products, and technology transfer.

In 2016, a solution in planting vegetables via smart phones was developed by the agriculture start-up Hachi and it obtained remarkable outcomes. This system uses the Internet of Things (IoT) to design crop apps, which are convenient for customers living in the city. Risks in the planting process such as drought and soil nutrition shortages are reduced by the assistance of the application. As a result, productivity increases from 30 to 50 percent compared to traditional planting methods and more importantly, it can also be applied to rice plantations. First, farmers enter data relating to the status of their rice crops through a smartphone app, which is then sent to a processing unit. Second, based on information about soil, climate, and plant growth, a quick summary with advice is then recommended to farmers.

High-tech agriculture should meet three basic requirements, namely economies of scale, linkage to value chains, and ensuring bargaining power of farmers. However, the majority of agriculture models are just in a period of transformation, with small land plots and backward technology, and consequently, it is very difficult to apply high-tech to large-scale agriculture. Moreover, land is another issue that interrupts both domestic and foreign investors to invest in Vietnam's agriculture sector. The starting point of agriculture in Vietnam is at a low level and inferior in both information technology (IT) application and production compared to other countries in both regional and international levels. Rugged terrain in the mountainous areas is also a constraint to building up a good Internet network, which is an essential condition to implement high-tech agriculture. The credit support policy for high-tech agriculture is ineffective because the application of high-tech requires a huge amount of investment, while capital recovery is slow. The shortage of highquality human resources to manage and operate modern equipment is another problem for Vietnam to implement high-tech agriculture. With large-scale agricultural production, farmers should be agricultural workers and shareholders of agricultural enterprises (Luu Tien Dung \& Nguyen Thi Kim Hiep, 2017). 
The application of ICT in Vietnamese agriculture is still in its early stages. Some enterprises have started to provide services that support decision-making by providing information on weather, production methodologies, or markets. Some have also established experimental farms, allowing them to measure the effectiveness of their production system using ICT equipment. Although there has not yet been sufficient analysis of these experiments, there is a growing expectation that ICT application will make agriculture more efficient and create more added value. Given urban consumers' increasing interest in "safe" or "green" products and the growing presence of foreign retailers, demand for precision agriculture will surely increase in the future. Increased opportunities to export agricultural products thanks to Vietnam's participation in free trade agreements will also increase demand for ICT applications since those products must be produced in accordance with importers' certification requirements. The increased connectivity brought by ICT may also benefit the many who have recently shifted to these new commodities, including corporate farms and the farmers who switched from grain to non-grain crops, who will need information on production methodology and markets. Moreover, ICT application is also expected to enable more efficient production, reduce water use and other inputs, and reduce the labor requirements (Sakata, 2019).

\section{Opportunities and Challenges for High- tech Agriculture in Vietnam}

\section{Opportunities}

In order to respond to climate change and ensure food security and agricultural sustainability, the Government of Vietnam has adopted the "National Target Program to Respond to Climate Change and Rising Sea Levels" and the "Green Growth Strategy in the period 2011-2020, with a vision toward 2050" as well as developing organic farming methods and safe agriculture in Vietnam through collaborations with international organizations. Sustainable agricultural development usually concentrates on technologies such as preventing soil erosion, protecting soil and soil moisture, calculating farming possibilities, and terrace field methods for sloping terrains to increase vegetation covers; adopting active irrigation by building reservoirs and applying more effective methods like spraying and dripping; and designing complete processes for fertilization, nutrition, and wastewater treatment.

Due to the development care of agricultural authorities as well as strengthening international investments for environment and climate change adaptations, high-tech agriculture development of Vietnam has made progress in recent years. Vietnamese enterprises have opportunities to access soft loans or non-refundable aids for agricultural practices towards environmental protection and adaptations to climate change from the UK Aid, the Australian Aid, the World Bank, and the ADB through the Vietnam Business Challenge Fund (VBCF), Vietnam Inclusive Innovation Project (VIIP), and other projects financed by the World Bank and coordinated by the Ministry of Planning and Investment (Nguyen Huu Ninh \& Hoang Thi Bich Hop, 2019).

\section{Challenges}

Although there are many opportunities for developing high-tech agriculture in Vietnam, the country is also facing various challenges. Hightech agriculture development not only requires a full legal basis but also needs synchronous technological development, risk management, and risk forecast systems as well as enhancing international cooperation and facilitating massive participation of the private sector in agricultural production through public-private partnership (PPP) to expand economic opportunities for the private sector to ensure efficient agricultural production.

Although the cooperation pattern between authorities, scientists, enterprises, and farmers has been expanded in agricultural production of Vietnam in recent decades, this pattern must overcome numerous existing bottlenecks. These challenges include an inconsistent environment for the engagement of the private sector in agricultural production and a shortage of 
investment capital in agriculture due to high risk, slow capital recovery, and low profitability.

Further, a lack of truth between parties in agricultural contracts is defined as another challenge. Both enterprises and farmers may easily break contracts signed in the cases that firms are unable to process and sell final products to the market or farmers sell their products to merchants to obtain higher prices. In addition, scientific and technical farming improvements in Vietnam lag behind advanced countries and the process of technology transfer from foreign counties to Vietnam is expensive.

Finally, Vietnam is one of the largest riceexporting countries in the world. Climate change affects not only Vietnam but also food security in the region and the world. According to an estimation of the United Nations in 2013, the global population will continue to rise, and the world's population is predicted to reach 8.2 billion in 2025 and 9.6 billion in 2050 . Worldwide agricultural production is more complex due to the adverse effects of climate change. Thus, Vietnam should promote regulations for a green and adaptive agricultural economy and support small and medium-sized enterprises to take part in global value chains that look toward sustainable development (Nguyen Huu Ninh \& Hoang Thi Bich Hop, 2019).

\section{Conclusions and Policy Implications}

This article aims to examine the importance and development of high-tech agriculture in Vietnam under the context of industrialization and urbanization. Due to pressure from international economic integration and climate change in recent years, high-tech agriculture can be identified as a feasible direction for Vietnam to renovate the agricultural sector. Although high-tech agriculture has existed in different locals and sub-sectors of agriculture such as crop, livestock, and aquaculture, and Vietnam has gained initial achievements in adopting high-tech agriculture, this country has to face a number of challenges related to land, credit, IT, and human resources in the process of developing high-tech agriculture.
There are several policies we recommended that should be implemented to facilitate the development of high-tech agriculture in Vietnam. First, high-tech agriculture must be considered as the top priority in agricultural reform. The government should clarify and solve land issues in order to encourage land accumulation for large-scale agricultural development. Specifically, quotas on agricultural land in the 2013 Land Law need to be removed or loosened to establish large-scale agricultural zones that are suitable for adopting high-tech agriculture. Second, implementation of consistent credit policies that assist businesses and farmers to develop and apply high-tech agriculture. For instance, a credit package worth 100 trillion VND (4.4 billion USD) to invest in the development of high-tech agriculture at lower than market rates provided by the government is necessary to encourage, support, and promote the development of high-tech farming applications. Third, the country should continue to improve policies on the promotion of research, innovation, incubation, transfer, technology development, and technology application to agricultural production, with an emphasis on policies to promote the scientific and technological potential of the contingent of scientists to assist enterprises in developing hightech agriculture. Fourth, the country should encourage both domestic and foreign enterprises to invest in high-tech agriculture. To tackle this assignment, the government should introduce more specific policies in both medium and long terms. The public-private partnership model should be promoted to attract more investments in agriculture. Fifth, partnerships among the State, scientists, businesses, and farmers should be consolidated to ensure success of adopting high-tech agriculture. For example, the State should focus on constructing and releasing macro policies related to land, credit, taxes, science and technology, and human resource management. Scientists have responsibilities in researching and inventing new varieties, technology, and practices that can be adopted in high-tech agriculture. Enterprises and farmers are in charge of investing and implementing high-tech agriculture models. Finally, high-tech agriculture 
should be integrated into the programs on new rural and agricultural extensions to efficiently exploit resources and improve outcomes.

\section{References}

Nguyen Thi Ngoc Anh (2020). The role of technology in high-tech agricultural development in the context of social, ecological and economic transformation in Vietnam. VNU Journal of Science: Policy and Management Studies. 36(1): 8-18.

Clercq M. D., Vats A. \& Biel A. (2018). Agriculture 4.0: The future of farming technology. World Government Summit in Collaboration with Oliver Wyman. February 2018.

Nguyen Xuan Cuong (2019). Development of sustainable high-tech agriculture. Journal of Propaganda. Retrieved from http://tuyengiao.vn/kinh-te/phat-triennong-nghiep-cong-nghe-cao-ben-vung-122963 on April 20, 2020 (in Vietnamese).

Duong Anh Dao (2012). Study on the development of hightech agriculture in Can Tho city. Master Thesis in Geography. Ho Chi Minh City University of Education, 2012 (in Vietnamese).

EU (2014). Precision agriculture: An opportunity for EU farmers - potential support with the CAP 2014-2020. Retrieved from http://www.europarl.europa.eu/RegData/etudes/not e/join/2014/529049/IPOL-AGRI_NT on December $15,2020$.

FAO (2020). Agriculture total. Carbon dioxide emissions in agriculture of Vietnam. Retrieved from http://www.fao.org/faostat/en/\#data/GT on April 20, 2020.

Gebbers R. \& Adamchuk V. I. (2010). Precision agriculture and food security. Science. 327(5967): 828-831.

General Statistics Office of Vietnam (2017). Statistical Yearbook of Viet Nam 2016. Statistical Publishing House, Hanoi (in Vietnamese).

$\mathrm{Vu}$ Thi Thuy Hang (2019). Development of high-tech agriculture in India and experience lessons for Viet Nam. Number \& Events. Retrieved from http://consosukien.vn/san-xuat-nong-nghiep-ungdung-cong-nghe-cao-o-an-do-va-bai-hoc-cho-vietnam.htm on April 20, 2020 (in Vietnamese).

Le Tat Khuong \& Tran Anh Tuan (2014). Some reflections on hi-tech application for agriculture development in Vietnam - Experiences and lessons learnt from China. Journal Science and Technology Policies and Management. 3(1): 48-59 (in Vietnamese).

Luu Tien Dung \& Nguyen Thi Kim Hiep (2017). The revolution of agriculture 4.0 and sustainable agriculture development in Viet Nam. International conference proceedings: Emerging issues in economics and business in the context of international integration. National Economics University, Ha Noi, December 2017. 317-328.
Nguyen Huu Ninh \& Hoang Thi Bich Hop (2019). Climate smart agriculture for development in Vietnam: Opportunities and challenges. Retrieved from http://en.vbcsd.vn/detail.asp?id=481 on May 20, 2019.

Ong B. (2017). Development of high-tech agriculture in Vietnam. Retrieved from https://publicpolicy.wharton.upenn.edu/live/news/203 6-development-of-high-tech-agriculture-in-vietnam on April 20, 2020.

Nguyen Thu Phuong (2018). Managerial and development experience in high-tech agriculture in some countries and preference values. Industry and Trade Magazine. Retrieved from http://www.tapchicongthuong.vn/baiviet/kinh-nghiem-quan-ly-phat-trien-nong-nghiepcong-nghe-cao-o-mot-so-nuoc-va-gia-tri-tham-khao55028.htm on April 20, 2020 (in Vietnamese).

PRD (The Government Public Relation of Thailand) (2017). Intelligent SMES and smart agriculture in response to Thailand 4.0 policy. Retrieved from https://thailand.prd.go.th/main.php?filename=index on December 15, 2020.

Sakata S. (2019). The application of information and communication technologies (ICT) in agriculture: Present status, opportunities, and challenges in Vietnam. New Trends and Challenges for Agriculture in the Mekong Region: From Food Security to Development of Agri-Businesses, BRC Research Report, Bangkok Research Center, JETRO Bangkok/IDE-JETRO, 2019.

Nguyen Thanh Tuan \& Nguyen Duc Hoang Tho (2020). Developing high-tech market and sustainable agriculture in Israel: Policy implications for Vietnam.

World Bank (2011). Vietnam urbanization review. Technical Assistance Report. World Bank, November 2011.

World Bank (2016). Transforming Vietnamese agriculture: Gaining more from less. Vietnam Development Report 2016.

World Bank (2020a). World development indicators. Annual growth of agriculture, forestry and fisheries and GDP of Viet Nam. Retrieved from https://databank.worldbank.org/data/reports.aspx?sour $\mathrm{ce}=2 \&$ series $=$ EN.ATM.CO2E.KT\&country $=\#$ on April 20, 2020.

World Bank (2020b). World development indicators. Crop, livestock and food indices of Viet Nam. Retrieved from

https://databank.worldbank.org/data/reports.aspx?sour $\mathrm{ce}=2 \&$ series $=$ EN.ATM.CO2E.KT\&country $=\# \quad$ on April 20, 2020.

World Bank (2020c). World development indicators. Rate of agricultural land of Viet Nam. Retrieved from https://databank.worldbank.org/data/reports.aspx?sour $\mathrm{ce}=2 \&$ series $=$ EN.ATM.CO2E.KT\&country $=\# \quad$ on April 20, 2020.

World Bank (2020d). World development indicators. Rate of urban population of Viet Nam. Retrieved from 
Development of high-tech agriculture in the context of Industrialization and urbanization: The case of Vietnam

https://databank.worldbank.org/data/reports.aspx?sour $\mathrm{ce}=2 \&$ series $=$ NV.IND.TOTL.ZS\&country $=\#$ on April 20, 2020.

World Bank (2020e). World development indicators. Rate of urban population access to electricity in Vietnam. Retrieved from https://databank.worldbank.org/data/reports.aspx?source $=2$ \&series=EG.ELC.ACCS.ZS\&country=\# on April 20, 2020. 